The University of Maine

DigitalCommons@UMaine

Marine Sciences Faculty Scholarship

School of Marine Sciences

$4-1-2015$

\title{
Optical techniques for remote and in-situ characterization of particles pertinent to GEOTRACES
}

\author{
Emmanuel Boss \\ University of Maine, emmanuel.boss@maine.edu \\ Lionel Guidi \\ Observatoire Océanologique de Villefranche Sur Mer \\ Mary Jo Richardson \\ Texas A\&M University \\ Lars Stemmann \\ Sorbonne Universite \\ Wilford Gardner \\ Texas A\&M University
}

See next page for additional authors

Follow this and additional works at: https://digitalcommons.library.umaine.edu/sms_facpub

Part of the Oceanography and Atmospheric Sciences and Meteorology Commons

\section{Repository Citation}

Boss, Emmanuel; Guidi, Lionel; Richardson, Mary Jo; Stemmann, Lars; Gardner, Wilford; Bishop, James K.B.; Anderson, Robert F.; and Sherrell, Robert M., "Optical techniques for remote and in-situ characterization of particles pertinent to GEOTRACES" (2015). Marine Sciences Faculty Scholarship. 229. https://digitalcommons.library.umaine.edu/sms_facpub/229

This Article is brought to you for free and open access by DigitalCommons@UMaine. It has been accepted for inclusion in Marine Sciences Faculty Scholarship by an authorized administrator of DigitalCommons@UMaine. For more information, please contact um.library.technical.services@maine.edu. 
Authors

Emmanuel Boss, Lionel Guidi, Mary Jo Richardson, Lars Stemmann, Wilford Gardner, James K.B. Bishop, Robert F. Anderson, and Robert M. Sherrell 


\title{
Optical techniques for remote and in-situ characterization of particles pertinent to GEOTRACES
}

\author{
Emmanuel Boss ${ }^{\mathrm{a}, *}$, Lionel Guidi ${ }^{\mathrm{b}}$, Mary Jo Richardson ${ }^{\mathrm{c}}$, Lars Stemmann ${ }^{\mathrm{d}}$, Wilford Gardner ${ }^{\mathrm{c}}$, \\ James K.B. Bishop ${ }^{\mathrm{e}}$, Robert F. Anderson ${ }^{\mathrm{f}}$, Robert M. Sherrell ${ }^{\mathrm{g}}$ \\ a School of Marine Sciences, 5706 Aubert Hall, University of Maine, Orono, ME 04473, USA \\ ${ }^{\mathrm{b}}$ Laboratoire d'Oceanographie de Villefranche (CNRS), Observatoire Océanographique de Villefranche, 181, Chemin du Lazaret, 06234 Villefranche sur mer, France \\ 'Texas A\&M University, 3146 TAMU, College Station, TX 77843, USA \\ ${ }^{\mathrm{d}}$ Sorbonne Universités (Université Pierre et Marie Curie, Paris 6), Observatoire Océanologique de Villefranche-sur-Mer, 06230 Villefranche-sur-Mer, France \\ e University of California Berkley, 499 McCone Hall, Berkeley, CA 94720, USA \\ ${ }^{\mathrm{f}}$ Lamont-Doherty Earth Observatory of Columbia University, 231 Comer, 61 Route 9W, PO Box 1000, Palisades, NY 10964, USA \\ ${ }^{\mathrm{g}}$ Institute of Marine and Coastal Sciences, Dept. of Earth and Planetary Sciences, Rutgers University, 71 Dudley Rd., New Brunswick, NJ 08901, USA
}

\section{A R T I C L E I N F O}

\section{Article history:}

Available online 14 October 2014

\begin{abstract}
A B S T R A C T
Field and laboratory characterization of marine particles is laborious and expensive. Proxies of particle properties have been developed that allow researchers to obtain high frequency distributions of such properties in space or time. We focus on optical techniques used to characterize marine particles in-situ, with a focus on GEOTRACES-relevant properties, such as bulk properties including particle mass, crosssectional area, particle size distribution, particle shape information, and also single particle optical properties, such as individual particle type and size. We also address the use of optical properties of particles to infer particulate organic or inorganic carbon. In addition to optical sensors we review advances in imaging technology and its use to study marine particles in situ. This review addresses commercially available technology and techniques that can be used as a proxy for particle properties and the associated uncertainties with particular focus to open ocean environments, the focus of GEOTRACES.
\end{abstract}

() 2014 Elsevier Ltd. All rights reserved.

\section{Introduction to the role of particles in GEOTRACES}

Riverine particles and atmospheric aerosols serve as input of trace elements to seawater. Trace elements are removed from seawater by active uptake by phytoplankton, subsequent grazing and sedimentation as well as via adsorption to particles. They are also internally recycled within the ocean through physical and biogeochemical processes (for recent summaries, see Anderson and Hayes, 2014; Jeandel et al., 2015). Consequently, an accurate knowledge of the abundance, distribution and composition of particles in the ocean is essential to the mission of the GEOTRACES program, an international study of the marine biogeochemical cycles of trace elements and their isotopes <www.geotraces.org $>$. Collection of particles in discrete samples, followed by the chemical characterization of particle composition, is widely used in GEOTRACES to define the role of particles in trace element cycles (Lam et al., 2015; McDonnell et al., 2015). The inherent spatial

\footnotetext{
* Corresponding author.

E-mail addresses: emmanuel.boss@maine.edu (E. Boss), lguidi@obs-vlfr.fr (L. Guidi), mrichardson@ocean.tamu.edu (M.J. Richardson), stemmann@obs-vlfr.fr (L. Stemmann), wgardner@ocean.tamu.edu (W.D. Gardner), jkbishop@berkeley.edu (J.K.B. Bishop), boba@ldeo.columbia.edu (R.F. Anderson), sherrell@marine.rutgers. edu (R.M. Sherrell).
}

and temporal limitations of discrete sampling potentially introduce a bias into the interpretation of the results due to an incomplete description of the particle field.

Optical techniques allow for sampling at much greater spatial and temporal resolution, providing a more informed context for interpreting the results from discrete samples as documented below (Fig. 1). In addition, preliminary application of optical techniques during early GEOTRACES cruises has helped to establish an important role for intermediate and benthic nepheloid layers particles in the removal of radionuclides and, presumably, of other trace elements from seawater (Deng et al., 2014; Hayes et al., in press). Information presented in this review will facilitate the incorporation of additional sophisticated optical techniques in future GEOTRACES expeditions. This information will also be of value in planning other programs, such as those studying the marine biogeochemical cycles of carbon, of major nutrients, and of anthropogenic contaminants.

\section{Optical properties and their sensitivity to mass, size, composition, shape, and packing of marine particles}

Inherent optical properties (IOP) of seawater and its constituents are independent of sun illumination and can be measured in 
the laboratory and the field. Absorption and angular scattering are the processes through which monochromatic (i.e. narrow wavelength band) and collimated (i.e. highly directional) light from a source is lost out of a light beam through annihilation or redirection, respectively. The attenuation coefficient $(c)$ is the sum of the absorption coefficient $(a)$ and the scattering coefficient $(b)$, which is the integral of all directions of angular scattering. An additional IOP is inelastic scattering; the process whereby light absorbed at one wavelength is emitted at another wavelength.

To first order, optical properties of particles vary with concentration. To second order, they vary with size, shape, internal structure and packing. While the interaction of matter with light is complicated (e.g. Jonasz and Fournier, 2007, and Sosik, 2008, for recent reviews), some generalizations can be made, in particular with respect to the effect of particle size. For particles much smaller than the wavelength, scattering is fore-aft symmetric and decreases as wavelength to the negative 4th power, whereas absorption for such particles is proportional to their volume. For particles much larger than the wavelength, absorption, scattering and attenuation correlate with cross-sectional area (i.e. their shadow, e.g. Jonasz and Fournier, 2007), exhibiting relatively little spectral variations in scattering, and hence are relatively insensitive to composition. To first order, the mass normalized optical property of a single particle can be predicted by the ratio of its size (e.g. the diameter of a sphere with a similar cross-section) to the wavelength of light times the difference between its index of refraction and that of water (e.g. Figs. 3-6 in Stemmann and Boss, 2012). While mass normalized absorption decreases approximately monotonically with particle size (Duysens, 1956), mass normalized scattering exhibits a resonance behavior as a function of size. Scattering reaches a maximum for particles of a few microns, then decreases as diameter ${ }^{-1}$ for larger solid particles (Baker et al., 2001; Fig. 2).

Because particulate matter (PM) concentrations within the water column change over four orders of magnitude (e.g. PM varying from 5 to $>12,000 \mu \mathrm{g} \mathrm{kg}^{-1}$ as a function of depth and location in the open ocean, Brewer et al., 1976; Gardner et al., 1985), the primary variability in optical properties in the ocean (from the seawater and the particles) is due to particle concentration. Additionally, optical properties are sensitive to particle size, shape and composition. Angular scattering for particles is a strong function of particle size; in general, the larger the particle, the more the energy is

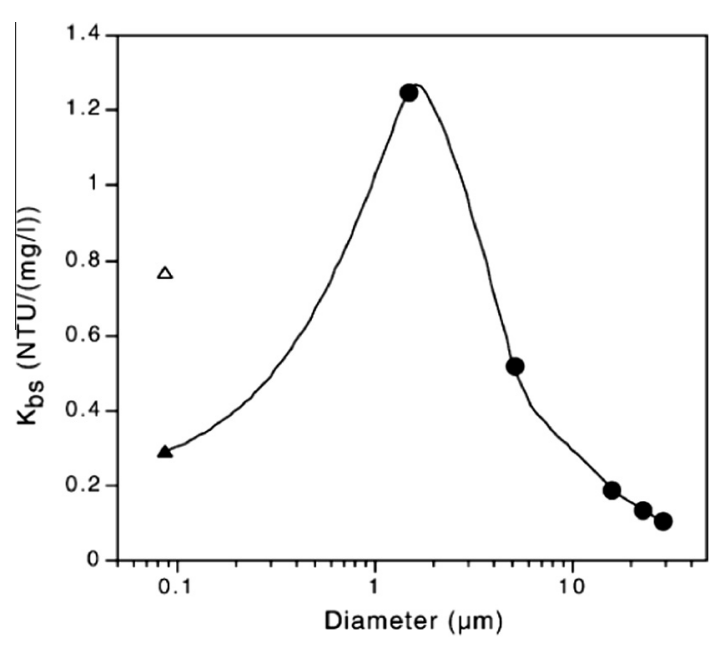

Fig. 2. Mass-specific side-scattering (reported as turbidity) values $\left(K_{b s}\right)$ as a function of size for plastic beads (triangles. Solid triangles is calculated for density of $2.65 \mathrm{~g} \mathrm{~cm}^{-3}$ ) and natural particles (solid circles) (from Baker et al., 2001). Note the resonance near 1 micron and the decrease as diameter ${ }^{-1}$ for larger sizes.

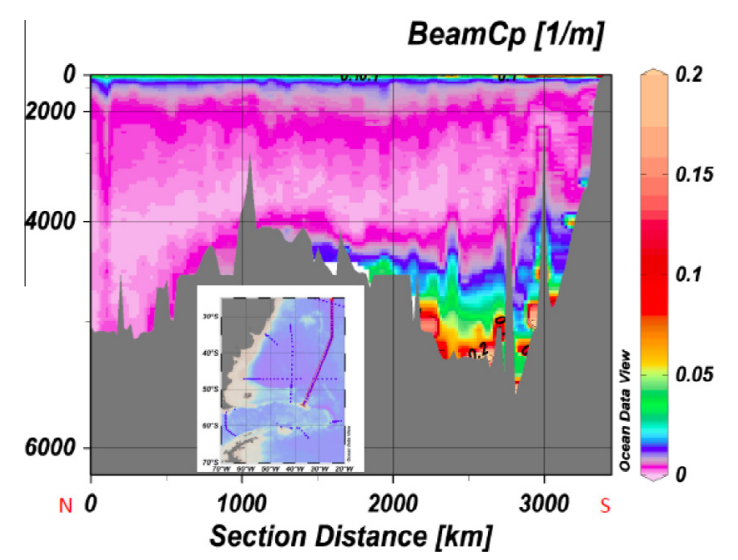

Fig. 1. Example of a section of beam attenuation coefficient due to particles $\left(c_{p}\right)$ collected during the South Atlantic Ventilation Experiment (SAVE) in February, 1989. Shows location of section (red) from North to South. A 25-cm path-length SeaTech transmissometer (acceptance angle $1.03^{\circ}$ ). Note bottom expansion of the depth scale for higher resolution. Concentrations of resuspended boundary sediments exceeded $1500 \mathrm{~g} \mathrm{I}^{-1}$ in the Argentine Basin (Wood, 1993; Gardner et al., 2014) but were seldom greater than $100 \mu \mathrm{g} \mathrm{l} \mathrm{I}^{-1}$ in the Brazil basin (Richardson et al., 1990). (For interpretation of the references to color in this figure legend, the reader is referred to the web version of this article.)

scattered in the same direction the light is propagating. Composition effects are mediated through the index of refraction of the material particles that are composed of both organic (lipids, sugar, proteins, starch) and inorganic materials (opal, calcite, clay minerals). These materials have indices of refraction that are significantly different from water $(n>1.12$, Aas, 1996, where $n$ is measured relative to water), and hence cause the particles to interact significantly with light (the more different the index of refraction of a particle relative to water, the more intense the scattering from that particle). Because phytoplankton and other organic particles (such as bacteria) often have a large fraction of their volume occupied by fluid, their 'effective' index of refraction (that is if we model them as homogeneous particles) is quite similar to that of water $(n \sim 1.05$, Aas, 1996).

For large populations of particles, composition was found to primarily modulate the ratio of backward to forward scattered light (e.g. Twardowski et al., 2001; Fournier et al., 2014). When the optical properties such as attenuation and scattering are normalized by dry-mass (that is without the interstitial water, as when obtaining dry weight PM), the mass specific optical property varies by only a factor of two between organic and inorganic particles (Babin et al., 2003).

Aggregation of oceanic particles most often results in particles having a large fluid fraction and significant amount of mass (Alldredge and Jackson, 1995), and so will change angular scattering while nearly maintaining mass normalized optical properties (Boss et al., 2009a; Slade et al., 2011). It has been observed that the bulk optical properties of particle populations are proportional to the total cross-sectional area of the disaggregated particles (e.g. as measured with Coulter counters, see for example Fig. A1, in Behrenfeld and Boss, 2006). Hence, aggregation and disaggregation of oceanic particles tend to have a relatively small effect on mass normalized optical properties, as the crosssectional area of the solid material is nearly conserved. However rare and large heterogeneous aggregates are not well sampled by bulk optical methods. For these aggregates, imaging methods are better (see below; McDonnell et al., 2015). Similar arguments as for heterogeneous aggregates may apply to transparent exo-polymers (TEP, whose primary material is made from high index of refraction building block, but with a lot of added water, Alldredge et al., 1993). 


\section{Commercial technology to measure optical properties in-situ}

Commercially available in-situ optical instruments can be used to obtain estimates of the beam-attenuation, backscattering, sidescattering and absorption coefficients, which are then used as proxies for particle concentration. A list of worldwide datasets with such measurements is provided in Appendix A. The reason we use the word estimate is that no instrument measures exactly the property it is supposed to measure. Attenuation meters have a finite acceptance angle, which results in a de facto upper size cutoff sensitivity to particles (Boss et al., 2009b), and, when path length is short and/or particle concentrations are large, may be biased due to multiple scattering (e.g. Leymarie et al., 2010). Backscattering sensors measure light scattered at a single angle in the back direction. This single-angle measurement is used to estimate the full back-hemispherical scattering. This conversion has an associated uncertainty around $10 \%$ for typical marine particles (Boss et al., 2001a; Sullivan et al., 2013), and in very turbid conditions needs to be corrected for attenuation along the path. The exact angular response of side-scattering sensors is most often unknown and hence output is not in strictly physical units; rather it is calibrated with a turbidity standard. Finally, the vetted commercial instruments available for measuring the absorption coefficient in-situ (WETLabs ac-9 \& ac-S) have a deficiency in collecting all the scattered light and hence needs to be corrected in a procedure for which there is still no consensus and that introduces uncertainties on the order of a few tens of percent in the blue portion of the spectrum (e.g. Leymarie et al., 2010; Röttgers et al., 2013). Note, however, that a novel sensor has recently become commercial which should, in principle, provide in-situ absorption that does not need to be corrected for scattering (Turner Design's ICAM based on Fry et al., 1992). Given the above, comparing measurements by different sensors requires that instrument specifications are known and comparable.

Use of single optical properties to obtain particle mass, size and composition

The introduction of the first commercial transmissometers spawned the investigation of PM and particulate organic carbon concentration (POC) relationships with beam attenuation coefficient (Bishop, 1986, 1999; Bishop et al., 1999, 1992; Bishop and Joyce, 1986; Bishop and Wood, 2008; Cetinic et al., 2012; Gardner, 1989a; Gardner et al., 1985, 2003, 1993; Hill et al., 2011; Karageorgis et al., 2008, 2014; Neukermans et al., 2012). The beam attenuation coefficient was found to be a better proxy for POC than for PM for waters dominated by biogenic particles, having a smaller intercept and a significantly higher correlation coefficient (Bishop, 1999; Gardner et al., 2003).

Remote sensing requirements and the need to understand coastal and near bottom processes, stimulated the development of PM/POC - backscattering proxies (Boss et al., 2009c; Cetinic et al., 2012; Neukermans et al., 2012; Stramski et al., 1999). The availability of relatively cheap and large-depth capable side-scattering (turbidity) sensors encouraged studies relating side-scattering and POC or PM (Baker et al., 2001; Bishop and Wood, 2008; Boss et al., 2009c; Bishop et al., 2012; Cetinic et al., 2012).

Gardner et al. (1993) found in a North Atlantic study, that inclusion of the particles settling to the bottom of a Niskin bottle (Gardner, 1977) made no significant improvement to the correlation between PM and $c_{p}$; it did, however, increase the slope of the regression by $40 \%$, demonstrating that the settled particles (likely large aggregates) contributed significantly to $c_{p}$. Bishop and co-workers (Bishop, 1999; Bishop et al., 1999; Bishop and Wood, 2008, and Bishop et al., 2012) have found that inclusion of the $>51 \mu \mathrm{m}$ particle size-fraction improves the correlation of POC to $c_{p}$ relationships. They found that a single scaling factor relates POC and $c_{p}$ in oligotrophic waters near Hawaii and in productive waters of the Oyashio (see Fig. $3 \mathrm{AB}$ ). In contrast, they found sidescattering data to severely underestimate euphotic zone POC concentrations (Fig. 3CD). Cetinic et al. (2012), using data from the North Atlantic, have found that POC to $c_{p}$ relationships hold equally well above and below the euphotic layer. In contrast, they found that backscattering $/ c_{p}$ and side-scattering $/ c_{p}$ ratio varied with depth.

The variability in mass specific optical properties, when compared across studies, has been found to be constrained within $\pm 50 \%$ despite some variability in the analytical methods used to obtain mass (Boss et al., 2009c; Cetinic et al., 2012; Hill et al., 2011; Neukermans et al., 2012) and large variability in the environments sampled. Note that in all these studies measurements have been done using red or near-infra-red wavelengths ( $650 \mathrm{~nm}<\lambda<880 \mathrm{~nm}$ ) to minimize the effect of dissolved substance absorption on the attenuation coefficient, as well as to minimize the effect of particulate absorption on the scattering coefficient.

Shifrin (1988) has introduced the 'method of fluctuation' whereby fluctuation in beam attenuation can be used to provide an average particle size estimate. Briggs et al. (2013) have developed a similar method (though derived differently) to obtain an average particle size from backscattering and beam attenuation and have validated it in the laboratory against an established method (laser diffraction). The isolation of spikes in beam attenuation coefficient and scattering signals has been shown to be an index of both zooplankton and aggregate particles (Bishop and Wood, 2008; Gardner et al., 2000).

As noted above, there are locations where local or advected resuspended sediments increase particle concentrations and the associated $c_{p}$. These occurrences can be understood with the additional measurement of the backscattering ratio (see below). During the GEOTRACES program, evidence of active resuspension and deposition has been found to be important in scavenging some particle-reactive radionuclides in bottom waters (Hayes et al., in press; Anderson and Hayes, 2015) and is likely to have other biogeochemical impacts waiting to be discovered. Global mapping of areas of resuspension is needed for determining likely sites for further exploration (e.g., Gardner et al., 2014, Fig. 1).

\section{Combination of several optical properties}

\section{Spectral optical properties}

Spectral beam attenuation of particles (the difference between measurements of unfiltered samples minus those filtered by an in-situ $0.2 \mu \mathrm{m}$ filter) has been shown to provide a robust size index of particles in the size range of 0.2-20 $\mu \mathrm{m}$ (Boss et al., 2001a; Slade et al., 2011). A relationship between the particle beam attenuation spectral-slope and a power-law particulate size distribution (PSD) is predicted by idealized theory (e.g. Mie theory which assumes particles are spheres and of homogeneous optical properties, e.g. Boss et al., 2001b). A commercial switching device (FlowControl) to automate the filtered/non-filter technique for in-line or in-situ measurements of particulate properties has recently been commercialized (Sequoia Scientific). Spectral absorption of particles has been measured in situ using the same filtration system at both low and high spectral resolution. Low spectral resolution data has been used to estimate in-situ chlorophyll concentration from the peak height of the $676 \mathrm{~nm}$ Sorret band in an oligotrophic lake (Davis et al., 1997; Boss et al., 2007). High spectral resolution particulate absorption data were shown to provide concentrations of in-situ phytoplankton pigments and hence to extract information on the underlying phytoplankton population (Moisan et al., 2011; Chase et al., 2013). 


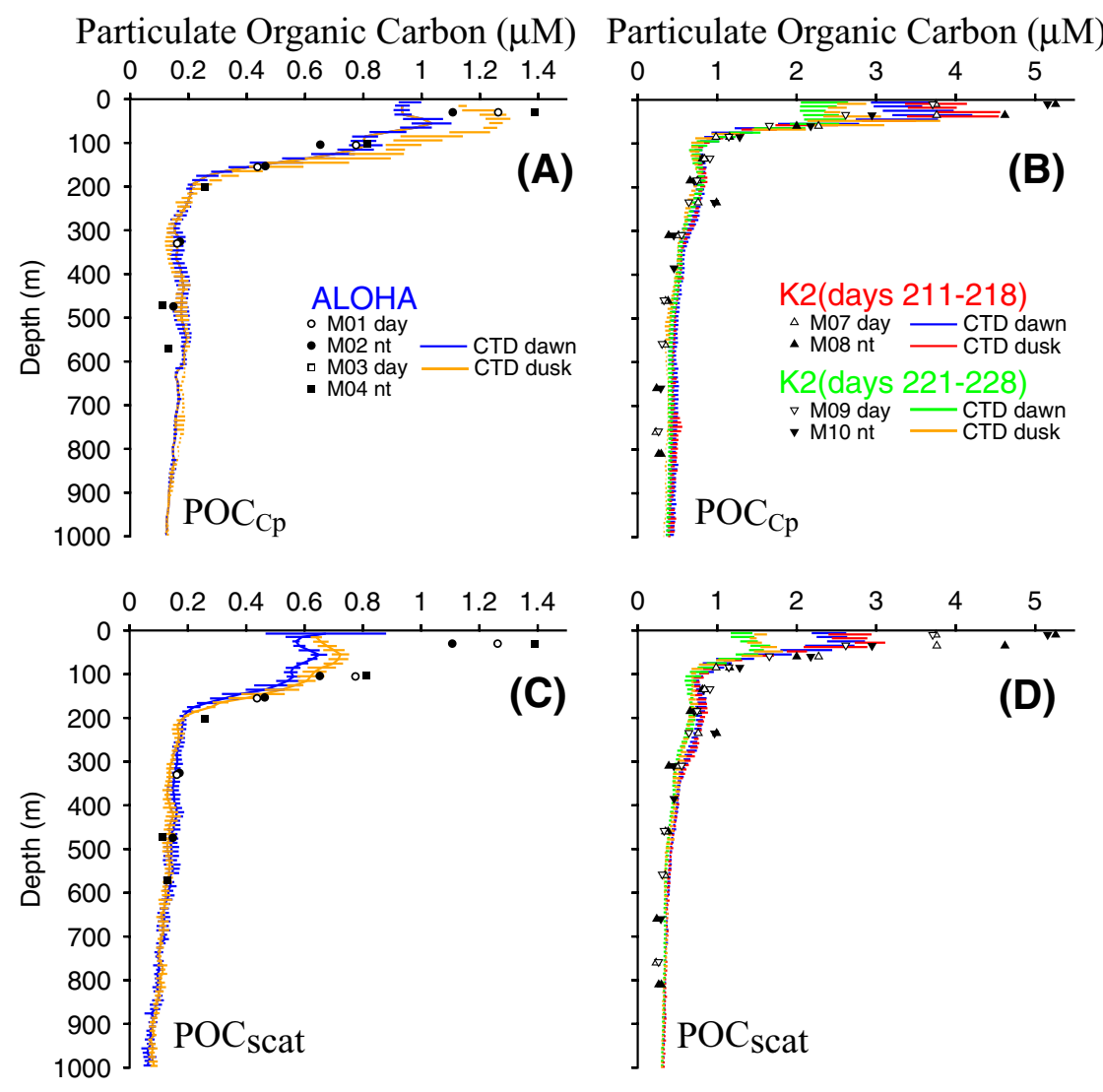

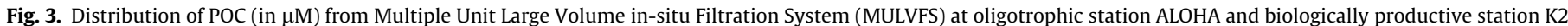

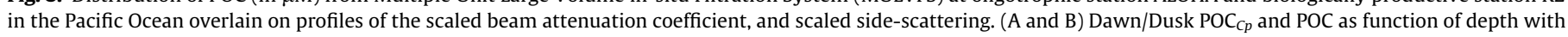

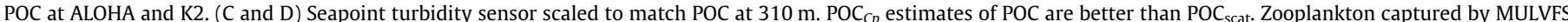

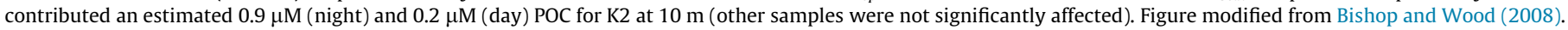

Most recently, a method that estimates the iron content of lithogenic particles using their absorption at blue wavelengths has been described (Estapa et al., 2012). Such a method, if proved to work with in-situ sensors, could pave the way for measurement of in-situ particle bound iron.

Since the 1960s fluorescence measurements have been used regularly to sample phytoplankton pigments in situ. This method is used to quantify pigments in situ and to differentiate phytoplankton functional types. Interpretation of the signals is not trivial particularly if quantitative results are sought (see recent review by McIntyre et al., 2010).

\section{Multiple angle scattering}

Diffraction-based techniques have been used for fifteen years to obtain size resolved information of PSD in situ (that is, which minimally affect aggregation state) by inversion of near-forward scattering measurements made using the Laser In Situ Scattering and Transmissometry (LISST) family of in situ sensors (Agrawal and Pottsmith, 2000). Sizes resolved with different LISST instruments span from about 2 to $500 \mu \mathrm{m}$. The inversion is most sensitive to a particle's cross sectional area. Hence, non-sphericity of marine particles results in smearing across size classes as different orientations are presented to the sensor (Karp-Boss et al., 2007) while providing a useful measure of the particulate cross-sectional area (which is proportional to the surface area for randomly oriented convex particles).

The LISST sensors were primarily designed to work in turbid environments (they have a 5-cm pathlength) and hence have a relatively low signal-to-noise ratio in clear water. Nonetheless several studies have used them in the upper ocean with success (Neukermans et al., 2012; Reynolds et al., 2010).

\section{Backscattering ratio}

The ratio of particle backscattering to the particle scattering coefficient, the backscattering ratio, has been found to be a useful descriptor of the bulk composition of the particle assemblage. It varies in the field by about a factor of 6 from $0.5 \%$ associated with phytoplankton to about 3\% associated with highly refractive lithogenic particles (e.g. Boss et al., 2009c; Loisel et al., 2007; Twardowski et al., 2001). An extreme value of $5 \%$ has also been reported (McKee et al., 2009).

\section{Optical sensing methods to obtain information on particulate inorganic carbon concentration}

\section{Cross-polarized transmission}

Birefringence refers to the ability of a mineral crystal to split an incident beam of linearly polarized light into two beams of unequal velocities (corresponding to two different refractive indices of the crystal), which subsequently recombine to form a beam of light that is no longer linearly polarized.

The extreme birefringence of $\mathrm{CaCO}_{3}$ makes it light up when the sample is held between crossed polarizers and viewed using transmitted light. This characteristic mineralogical property of $\mathrm{CaCO}_{3}$ is widely used as a means of identification. Calcium carbonate particles have an oceanic concentration range of $0.005-$ $40 \mu \mathrm{M}$. It has been demonstrated that a bench top spectropho- 
tometer can be used to detect particulate inorganic carbon (PIC, Guay and Bishop, 2002; IOCCG, 2011). Experiments with varying coccolith concentration in suspension with and without varying concentrations of non-birefringent material have established a linear concentration response to PIC. The measurement of birefringent photons requires simultaneous measurement of transmission to correct for scattering losses, although these losses are minor in most cases. Birefringence is measured as: $B=B_{o b s} /$ $T^{0.5}$, where $B=$ corrected birefringence, $B_{o b s}=$ raw birefringence signal and $T$ (as a fraction) is the measured fractional transmission (relative to particle free water) at the same wavelength. A low power $(<0.5 \mathrm{~W})$ PIC sensor has been used in diverse ocean environments ranging from polar regions to the equator, including oligotrophic to coastal and oxic to sub-anoxic environments (Bishop, 2009). The sensor has been under development (with WETLabs) since 2010 with deployments on CTDs in the subarctic N Pacific in 2012 and 2013. Repeat profiles at station PAPA show a detection limit of $0.01 \mu \mathrm{M}$ and deepwater reproducibility is $0.02 \mu \mathrm{M}$. Several mechanical/configuration issues have been identified that need to be addressed before the sensor is available commercially.

\section{Acid-labile method}

"Acid labile backscattering" is calculated as the difference between total and acidified backscattering (measured after adding a weak acid in order to drop the $\mathrm{pH}$ of the seawater/particle suspension below the dissociation point for calcite, Balch et al., 2001). This setup is ideal for semi-continuous shipboard measurements over a variety of spatial and temporal scales. Typically, acid-labile backscattering measurements can be made once every few minutes aboard ship, allowing spatial resolution of $\sim 1 \mathrm{~km}$ at typical ship speeds (e.g. Balch and Utgoff, 2009). Conveniently (and fortuitously), due to the typical coccolith backscattering cross section, the magnitude of the acid-labile backscattering (in units $\mathrm{m}^{-1}$ ) is approximately numerically equal to the PIC concentration (in moles $\mathrm{m}^{-3}$, Op. Cit.).

\section{Remotely-sensed ocean color}

Algorithms to obtain particle properties from ocean color remote sensing come in several varieties. Correlation-based algorithms are used to map chlorophyll (O'Reilly et al., 1998), POC (Son et al., 2009; Stramski et al., 1999, 2008), PM (Vantrepotte et al., 2011), PIC (Balch et al., 2007), and phytoplankton functional groups (Alvain et al., 2005; IOCCG, 2014). They tend to work best in open ocean conditions where the assumptions that phytoplankton and associated constituents co-vary and primarily modulate ocean color are valid. Semi-analytical algorithms have been developed which, in addition to empirical input, use radiative-transfer theory to invert optical constituents in the open ocean. These algorithms, most often, obtain the combined absorption of non-phytoplankton and dissolved material, phytoplankton absorption, the associated chlorophyll concentration, and the backscattering coefficient (see IOCCG, 2006; Werdell et al., 2013). Semi-analytical algorithms provide information regarding size (Loisel et al., 2006; Kostadinov et al., 2009; Berwin et al., 2011) and phytoplankton composition as well (Kostadinov et al., 2010).

A resource with examples using ocean-color remote sensing for a variety of ocean related studies with many case studies is provided at: http://www.ioccg.org/handbook.html. One is cautioned that many ocean-color based algorithms provide output without associated uncertainties. In addition, empirical algorithms that have been tuned with specific data obtained in a specific region at a given time may not be applicable to other conditions.

\section{Optical imaging of particle abundance and size distribution}

Relevant to the GEOTRACES objectives, imaging systems provide particle size spectra and characterize individual particles at high frequency. These are useful to estimate (1) macrozooplankton abundance (Checkley et al., 2008; Stemmann et al., 2008a), (2) particle flux through the water column (Guidi et al., 2008; Guidi et al., 2009; Jackson and Burd, 2002; Jouandet et al., 2011), and (3) particle size distribution in mesoscale spatial patterns (Guidi et al., 2012; see e.g. Fig. 4). They can be used to test the influence of particle size distribution on carbon and trace element (TE) fluxes (Bishop, 2009; Burd et al., 2007; Stemmann et al., 2004a; Stemmann et al., 2004b), and identify depths where aggregation takes place that may affect the distribution of elements (Burd and Jackson, 2009).

Optical imaging systems such as digital cameras have been used since the 1980s to study in-situ concentrations of particles larger than tens of micron including marine snow with an equivalent spherical diameter (ESD) $>500 \mu \mathrm{m}$ (Alldredge, 1998; Davis et al., 2005; Goldthwait and Alldredge, 2006; Gorsky et al., 1992; Honjo et al., 1984; McDonnell et al., 2015; Walsh and Gardner, 1992). Since then, the technology has evolved allowing fast laboratorybased or in-situ measurements of particle size distribution from a few microns to a few millimetres. The particle size range "seen" by these instruments is limited by the resolution of the imaging sensor and the volume of water sampled.

These instruments have been used to study biogeochemical cycles combining particle information from camera systems and sediment trap measurements of particle flux in order to better estimate particle sinking rate, a characteristic influencing particle export (Asper, 1987; Asper et al., 1992; Diercks and Asper, 1997; Gardner and Walsh, 1990; Guidi et al., 2008; Iversen et al., 2010; Jackson et al., 1997; Jouandet et al., 2011; McDonnell and Buesseler, 2010; Peterson et al., 2005; Walsh and Hunter, 1992). Systems such as the In Situ Ichthyoplankton Imaging System ISIIS (Cowen and Guigand, 2008), the Zooplankton Visualization and Imaging System ZOOVIS (Benfield et al., 2007) and the Shadowed Image Particle Profiler and Evaluation Recorder (SIPPER, Samson et al., 2001) allow counting and sizing of large zooplankton from images. The Video Plankton Recorder (VPR, Davis et al., 2005) and the Underwater Vision Profiler (UVP, Picheral et al., 2010) provide high temporal resolution particle imaging and size individual particles $>\sim 100 \mu \mathrm{m}$. However the larger water volume per image sampled by the UVP (Volume UVP $\sim 100$ times greater than the VPR) allows better estimation with higher vertical resolution of concentrations of rare large particles $(>1 \mathrm{~mm})$. Several systems utilizing holographic imaging such as the LISSTholo (Braithwaite et al. 2012) have also been developed for the purpose of imaging individual particles with sizes $>\sim 50 \mu \mathrm{m}$ in situ (Hobson et al., 1997; Katz et al., 1999; Alexander et al., 2000; Pfitsch et al., 2007). Other optical instruments such as the laser optical plankton counter (LOPC) can be used to quantify zooplankton and particles based on the opacity and size of particles (Checkley et al., 2008; Gonzalez-Quiros and Checkley, 2006; Jackson and Checkley, 2011). Validation is critical to insure particles are well identified.

While most of the instruments presented above allow imaging and measurement of large $(>100 \mathrm{~s} \mu \mathrm{m})$ particles there is increasing interest in quantifying nano- and microplankton particles. Laboratory, on-vessel or in-situ instruments such as the FlowCam (Flow Imaging), the Imaging FlowCytobot (McLane), or CytoSense 

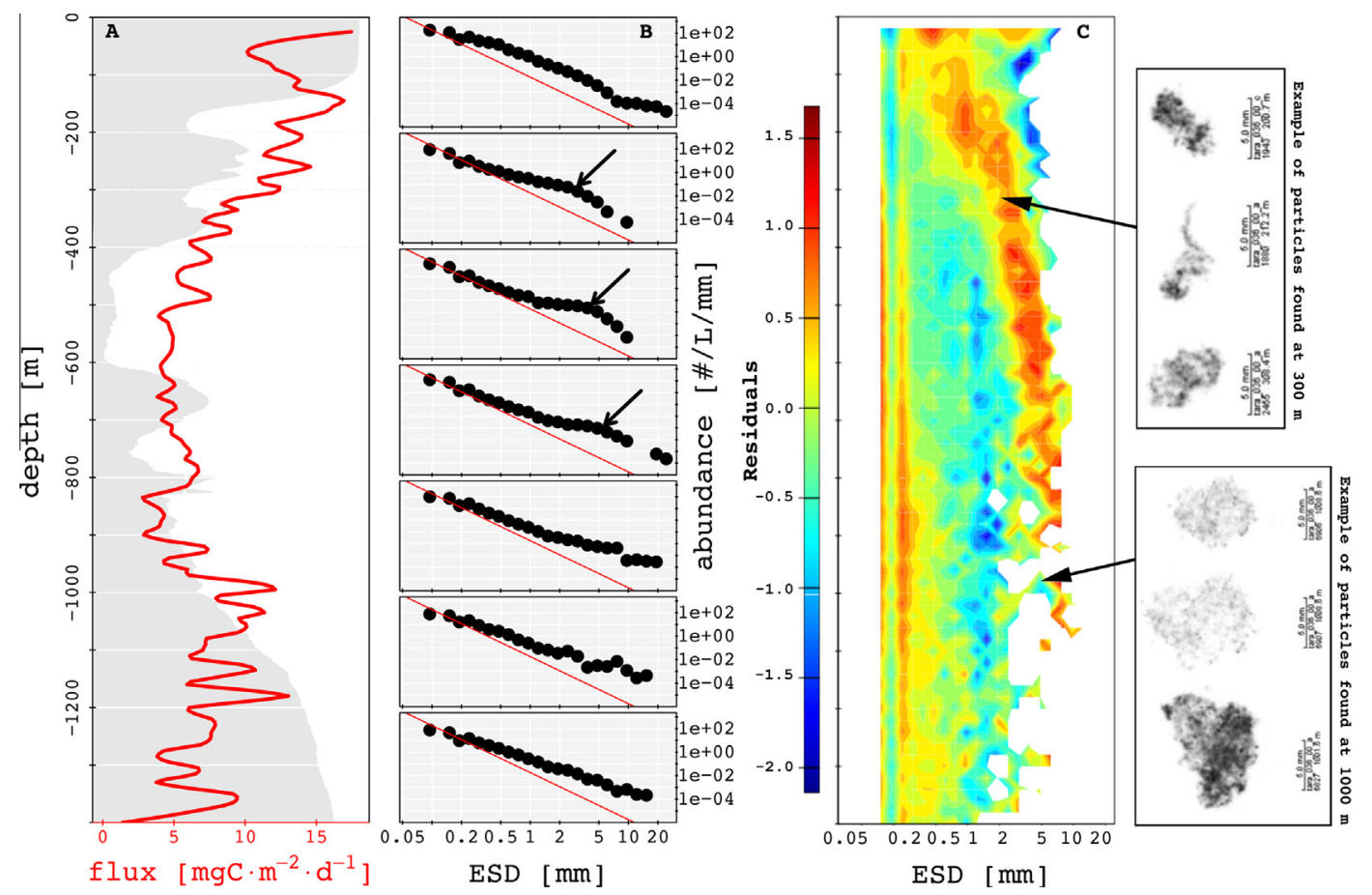

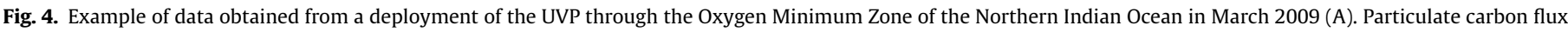

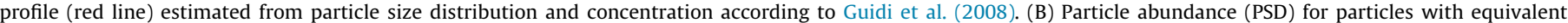

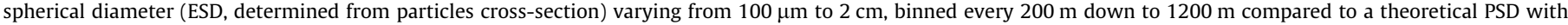

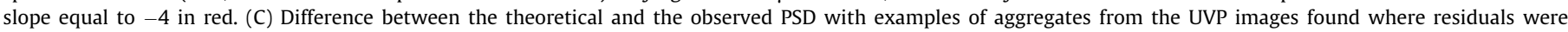

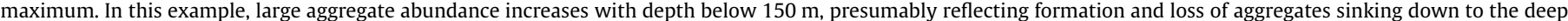
sea (Roullier et al., 2014). (For interpretation of the references to color in this figure legend, the reader is referred to the web version of this article.)

(CytoBuoy) allow this based on imaging and/or flow cytometery (Dubelaar and Gerritzen, 2000; Olson and Sosik, 2007; Sieracki et al., 1998).

\section{Deployment strategies}

Sensors to measure marine particles have been routinely deployed on CTD rosettes (Bishop and Joyce, 1986; Bishop et al., 1992; Bishop et al., 2012; Bishop, 1999; Bishop and Wood, 2008; Dickey et al., 2006; Gardner et al., 1985; Gardner et al., 1993; Gardner et al., 2001; Hill et al., 2011; Karp-Boss et al., 2004; Stemmann et al., 2008a), during deployments of large volume insitu filtration systems (Bishop, 1999; Bishop et al., 1999; Bishop et al., 2012; Bishop and Wood, 2008; Moran et al., 1999), on slow-drop packages (packages that fall under their own weight, Barnard et al., 1998), towed pumping systems, (Holser et al., 2011), AUVs and profiling floats (Bishop et al., 2002; Bishop and Wood, 2009; Bishop et al., 2004; Boss et al., 2008; Checkley et al., 2008; Dickey et al., 2008), submarines, bottom tripods (Gardner et al., 1985; Slade et al., 2011) and moorings (Dickey et al., 2006; Gardner, 1989a, 1989b; Richardson et al., 1993). Consideration of deployment platform should include potential of platform interference with particles (e.g. by inducing turbulence that break aggregates) and the ability of the platform to deal with the weight, size, power and data streaming demands of a particular sensor.

Optical technology for measuring particles and their properties that could enhance GEOTRACES cruises

Recommendations for sensors and sensor systems that could be included in GEOTRACES cruises to provide information regarding particles are provided in Table 1, with relationships between certain bulk particle properties and optical variables are provided in Table 2.
The US GEOTRACES intercalibration experiment cruises have provided a test bed for transmissometer scattering, and PIC sensor deployments during trace metal rosette casts and in-situ pump casts (e.g. Appendix B).

\section{Calibration strategies and resolution issues in nearly particle free oceanic waters}

Calibration and clean techniques with particle sampling and optical measurements are key to obtaining meaningful data in the open ocean as, often, the signals measured and samples collected are very close to the resolution and/or accuracy of the instruments/sampling-technique. This is well illustrated by the data of (Brewer et al., 1976), showing that the lowest and average $\mathrm{PM}$ in the deep North Atlantic are on the order of 5-6 $\mu \mathrm{g} \mathrm{kg}^{-1}$ and $20 \mu \mathrm{g} \mathrm{kg}^{-1}$, respectively. Using large volume in situ pumps in the upper $500 \mathrm{~m}$ of the water column, Bishop and Edmond (1976) found particle concentrations to be $20-100 \%$ higher than previously reported (Brewer et al., 1976), mostly due to adding the large-particle fraction. Gardner (1977) and Gardner et al. (1993) showed that inclusion of particles that have settled below the Niskin bottle sampling spigots increases particle concentrations by $10-100 \%$, which accounts well for the difference between bottle and pump concentrations reported by Bishop and Edmond (1976).

Assuming a conversion factor to beam attenuation of $0.8 \mathrm{~m}^{2} \mathrm{~g}^{-1}$ (based on the compilations of Gardner et al., 1985; Hill et al., 2011), the lowest and average $c_{p}$ at $660 \mathrm{~nm}$ are expected to be of the order of $0.005 \mathrm{~m}^{-1}$ and $0.015 \mathrm{~m}^{-1}$, respectively.

The digital output of $c_{p}$ from $25 \mathrm{~cm}$-long single band digital beam-transmissometers is reported to $0.001 \mathrm{~m}^{-1}$ resolution. Monitoring of analog output and digital count output from the sensors during laboratory bench top testing shows noise levels lower than $0.0003 \mathrm{~m}^{-1}$. Acquisition of digital count data from the CTD permits this level of precision to be achieved. Aboard ship, along-track 
Table 1

Sensors and sensor systems recommendations for GEOTRACES cruises.

\begin{tabular}{|c|c|c|}
\hline CTD-Rosette & In-Line (shipboard flow through) & Autonomous platforms \\
\hline $\begin{array}{l}\text { Commercial } \\
\text { Beam-transmissometer } \\
\text { Backscattering sensors } \\
\text { Turbidity sensors } \\
\text { Chlorophyll fluorometers } \\
\text { UVP }^{\text {a }}\end{array}$ & $\begin{array}{l}\text { Single band beam-transmissometer } \\
\text { Chlorophyll Fluorometer } \\
\text { Spectral absorption and attenuation meter. } \\
\text { Flow-cytometers }{ }^{\mathrm{e}} \\
\text { Imaging cytometers }^{\mathrm{f}} \\
\text { Automated particle imagers }{ }^{\mathrm{g}}\end{array}$ & $\begin{array}{l}\text { AUV and/or profiling floats with: } \\
\text { Beam-transmissometer, Backscattering or turbidity sensors. } \\
\text { Chlorophyll fluorometer. }\end{array}$ \\
\hline $\begin{array}{l}\text { Prototype } \\
\text { PIC sensor }\end{array}$ & $\begin{array}{l}\text { Filtered/unfiltered optical properties } \\
\text { PIC using acid-labile technique }\end{array}$ & $\begin{array}{l}\text { PIC sensor } \\
\text { Optical (imaging) } \\
\text { Sedimentation recorders }\end{array}$ \\
\hline
\end{tabular}

\footnotetext{
a Picheral et al. (2010).

b Bishop (2009).

c Slade et al. (2010).

d Balch and Utgoff (2009).

e Dubelaar and Gerritzen (2000).

f Olson and Sosik (2007).

g Sieracki et al. (1998).
}

Table 2

Summary table: Biogeochemical variables of particles and sensing technologies used to estimate them.

\begin{tabular}{|c|c|c|}
\hline Variables & Optical principle & Sensor types \\
\hline \multicolumn{3}{|l|}{ Mass concentration: } \\
\hline $\begin{array}{l}\text { Particle concentration (mass, } \\
\text { particulate organic carbon) }\end{array}$ & Transmission, scattering, imaging & $\begin{array}{l}\text { Transmissometers, backscattering and side-scattering sensors, } \\
\text { cameras }\end{array}$ \\
\hline Particulate inorganic carbon & Polarized transmission, acid- labile backscattering & $\begin{array}{l}\text { Custom transmissometers (PIC sensors), angular scattering sensors } \\
\text { with acid-injection. }\end{array}$ \\
\hline Phytoplankton pigments & $\begin{array}{l}\text { Fluorescence for chlorophyll-a like pigments and } \\
\text { Phycobiliprotein and particulate absorption }\end{array}$ & Single or multi-band fluorometers and/or spectorphotometers \\
\hline \multicolumn{3}{|l|}{ Particle size distribution } \\
\hline $\begin{array}{l}\text { Number, area, volume distributions } \\
\text { as function of size }\end{array}$ & Imaging, near-forward scattering & $\begin{array}{l}\text { Submersible cameras, Near-forward scattering sensors, Imaging } \\
\text { cytometers, Automated particle imagers. }\end{array}$ \\
\hline \multirow[t]{2}{*}{ Single size distribution parameter } & Slope of spectral particulate beam attenuation & Multi spectral transmissometers \\
\hline & Fluctuation in optical properties & $\begin{array}{l}\text { Single wavelength transmissometers, backscattering and } \\
\text { fluorometers }\end{array}$ \\
\hline \multicolumn{3}{|l|}{ Particle composition } \\
\hline $\begin{array}{l}\text { Bulk tendency between organic and } \\
\text { inorganic }\end{array}$ & $\begin{array}{l}\text { Ratio of backscattering to total scattering or beam } \\
\text { attenuation }\end{array}$ & $\begin{array}{l}\text { A backscattering sensor and spectral absorption and attenuation } \\
\text { sensor or near-infra-red transmissometer }\end{array}$ \\
\hline
\end{tabular}

transmissometers fed with surface water can achieve $0.0005 \mathrm{~m}^{-1}$ accuracy by taking the difference between two successive measurements with the same instrument, one with and one without a $0.2 \mu \mathrm{m}$ filter at the intake of a flow sleeve, and averaging over a minute of independent measurements (Boss et al., 2007; Slade et al., 2010).

Comparisons of sensors by Barnard and Claustre (personal communication 2012) and Bishop (CTD data R/V Point Sur, Feb 2012) demonstrated that (1) transmissometers are precise instruments (precision on the order of $0.001 \mathrm{~m}^{-1}$, and can be improved further by averaging), (2) transmissometers should be cleaned and calibrated by the users close to the time of measurements to significantly increase their accuracy (GEOTRACES has published a protocol on the appropriate procedures, see: http://www.geotraces.org/libraries/documents/Intercalibration/Cookbook.pdf), and (3) achieving highly accurate measurements in low particle concentration waters, is still a major challenge. Details of these comparisons are provided in Appendix B.

In terms of the back-scattering coefficient of particles, a minimum PM of $6 \mu \mathrm{g} \mathrm{kg}^{-1}$ with a mean around $20 \mu \mathrm{g} \mathrm{kg}^{-1}$ translates to about $5 \times 10^{-5}$ and $15 \times 10^{-5}$ at $660 \mathrm{~nm}$, where the uncertainties are on the order of $5 \times 10^{-5} \mathrm{~m}^{-1}$. To reach this level of accuracy, however, dark current measurements have to be determined on a separate cast with black tape on the receiver (Twardowski et al., 2007). Twardowski et al. (2007) found that between 300 and $500 \mathrm{~m}$ the difference between the backscattering signal at a red wavelength in the South Pacific ocean and the cleanest calibration waters was not significant.

Using turbidity meters it is possible to obtain higher resolution than with backscattering sensors. For example, Boss et al. (2008) obtained a minimal difference ( 7 counts) between the cleanest field water and the dark current. The higher resolution with turbidity meters is most likely due to the larger (though less well defined) sampling volume compared to backscattering sensors. The Seapoint turbidity meter, if measured to millivolt accuracy, has a resolution of 0.005 FTU (http://www.seapoint.com/stm.htm, equivalent to about $5 \times 10^{-5} \mathrm{~m}^{-1}$ in backscattering units). Precision can be improved using higher resolution analog to digital converters and by averaging.

Current technology to measure the absorption coefficient insitu has accuracy on the order of $0.005 \mathrm{~m}^{-1}$ or $0.01 \mathrm{~m}^{-1}$ (for $25 \mathrm{~cm}$ long WET-Labs's ac-9 and ac-S respectively), when calibrated with Nanopure clean water and for the red part of the spectra. Higher accuracy is possible if a calibration independent technique is used to obtain the particulate absorption $\left(0.001 \mathrm{~m}^{-1}\right.$, Boss et al., 2013), resulting in uncertainties in estimated chlorophyll on the order of $40 \%$ (Op. Cit.). Uncertainties associated with the scattering correction increase in absolute value at blue wavelengths and can be as high as 30\% (Röttgers et al., 2013). When absorption by inorganic particles is important, signif- 
icant errors in the particulate absorption coefficient in red wavelengths are observed (Op. Cit.).

Because detection and analysis of particles vary among different imaging systems, it is important to understand calibration procedures to ensure comparison of open ocean particle measurements. General calibration for optical instruments follows two critical steps: (1) calibration of the water volume for a single image and (2) calibration of the size of particle within the image. While particle counting is very sensitive to step 1, particle sizing depends on step 2 . The volume calibration can be performed in an aquarium filled with seawater with the light source illuminating a calibration sheet placed at different position in the field of light, and a digital camera recording the illuminated surface. Once all images are recorded, the volume can be reconstructed in 3D. An example of the volume calibration process can be found in Picheral et al. (2010). The size calibration on the other hand can be done using mainly 3 methods. For sufficiently large particles $(>100 \mu \mathrm{m})$ calibration can be done inserting known "natural" targets into the imaging system prior to taking measurements (e.g. Picheral et al. 2010). This allows calculating a calibration equation converting pixel area to real surface area of particles. When looking at smaller particles $(<100 \mu \mathrm{m})$ inserting and tracking them in the light field becomes impossible and calibrated beads or culture of phytoplankton cells are used to replace natural targets (Agrawal et al. 2008; Karp-Boss et al., 2007). Finally, cross-calibration of sensor output with a well characterized and calibrated sensor ('gold standard') can also be applied to insure inter-comparability of measurements.

Concentration has a critical impact on derived particle size distributions. For example, imaging instruments have seldom been used in oligotrophic systems where the principal technical challenge resides in the low concentration of particles $>500 \mu \mathrm{m}$. Since particle concentration decreases approximately exponentially with size, the illuminated volume must increase considerably in order to detect such particles and their statistics. For example, in the clearest water of the Pacific south gyre, collecting $100 \mathrm{ml}$ was found sufficient enough to detect particles up to $50 \mu \mathrm{m}$ while 751 of seawater was necessary to detect particles as large as $1000 \mu \mathrm{m}$ (Stemmann et al., 2008b).

From the discussion above it follows that the uncertainty associated with obtaining optical properties with current technology may not allow differentiation between a clear ocean water signal and a blank (the uncertainty in the signal is on the same order of magnitude as its difference from the cleanest calibration water available and heroic efforts need to be applied to do better). To improve on this situation, instrumentation and protocols need to be developed that can enable the robust determination of optical properties of particles in the deep ocean (e.g. using longer pathlength, stronger sources, more sensitive/stable receivers, better signal stabilization and calibration procedures). Specific calls for proposals by federal agencies (e.g. NSF-OTIC, NOPP or the SBIR programs in the USA) targeting the construction/refinement of novel/existing sensors that have good signal/noise characteristics, and for their validation in the clearest ocean waters, are needed to advance this field.

\section{Conclusions and recommendations}

Optical technologies can significantly aid the goals of the GEOTRACES program in constraining material pools and processes associated with trace elements. While some of the optical sensors are likely to be challenged in the clearest subsurface ocean waters, they will provide very useful data near the ocean's surface and bottom and will also be useful in detecting specific particle layers. GEOTRACES should include particle optics during CTD/rosette casts and during in-situ filtration system deployments and treat such data as core variables. The particulate samples, especially size fraction- ated samples collected by in-situ filtration, when analyzed for major constituent phases, would provide an especially valuable resource for GEOTRACES and for interpretation of optical signals. Optical sensors must be capable of full water column deployment and thus not interfere with cast operations. Further, at sea there must be scientific oversight of the optical data to ensure the quality of the data as it is collected. It is further recommended that a CTD-based intercalibration of multiple transmissometers, scattering and other candidate optical sensors in low particle waters would benefit data quality by providing the most stable instruments for major sections. The GEOTRACES program would benefit from the addition of in-line (shipboard flow through) optical sensors to provide information on horizontal distributions of particles within the mixed-layer.

\section{Acknowledgements}

This paper arose from the 3rd GEOTRACES Data-Model Synergy Workshop in November 2011 at Universitat Autònoma de Barcelona, Spain. Additional support for that workshop came from SCOR, through support to SCOR from the US NSF (Grant OCE-0938349 and OCE-1243377) and from a US NSF grant to the US GEOTRACES Project Office (OCE-0850963) and US NSF support for J Bishop (OCE 0964888). We thank Heidi Sosik and an anonymous reviewer for comments and editing suggestions, which significantly improved an earlier version of this manuscript.

\section{A. Appendix: Repositories where optical data can be found}

NSF funded, Biological and Chemical Data Management Office, bcodmo.org/.

ONR funded, Worldwide Ocean Optics Database (WOOD), wood.jhuapl.edu/wood/.

NASA's SeaWIFS Bio-optical Archive and storage system (SeaBASS), seabass.gsfc.nasa.gov/.

NOAA's National Ocean Data Center, www.nodc.noaa.gov/.

Texas A\&M transmissometer and POC data sets from JGOFS, WOCE, CLIVAR and others: ocean.tamu.edu/ pdgroup/SMP_prj/ DataDir/SMP-data.html or odv.awi.de/en/data/ocean/.

\section{B. Appendix: Recent inter-comparison exercises involving transmissometers}

In a comparison between ten new sensors deployed side-byside (Barnard, Claustre, 2012 personal communication), it was found that if users did not clean and calibrate the sensors themselves (that is relying on the manufacturer calibration and not cleaning the windows) differences between sensors readings could be as large as $0.05 \mathrm{~m}^{-1}$. Slight misalignment due to handling when instruments are shipped can cause significant deviation in readings. Conducting local calibration and cleaning the instruments improved agreement between instruments to within $0.01 \mathrm{~m}^{-1}$. Forcing all instruments to agree on the value at depth resulted in a difference between instruments that was on the order of $0.001 \mathrm{~m}^{-1}$.

Four transmissometers of two different designs (WET-Labs' CSTAR analog and digital instruments (CST 391 and CST 1450) and two prototype neutrally buoyant instruments, WET-Labs' POC017, POC018) were simultaneously profiled in deep California Current waters over 5 days at the same location (Bishop, unpublished data, 2012). Published GEOTRACES protocols for transmissometers were followed. Pooled sensor results for a low variability water layer between 1400 and $1600 \mathrm{~m}$ gave an average beam attenuation coefficient value of 0.0085 (s.d. 0.0033) $\mathrm{m}^{-1}$ (Fig. A1, Lerner et al., 2013). In contrast, each individual instrument repeated the $1400-1600 \mathrm{~m}$ 


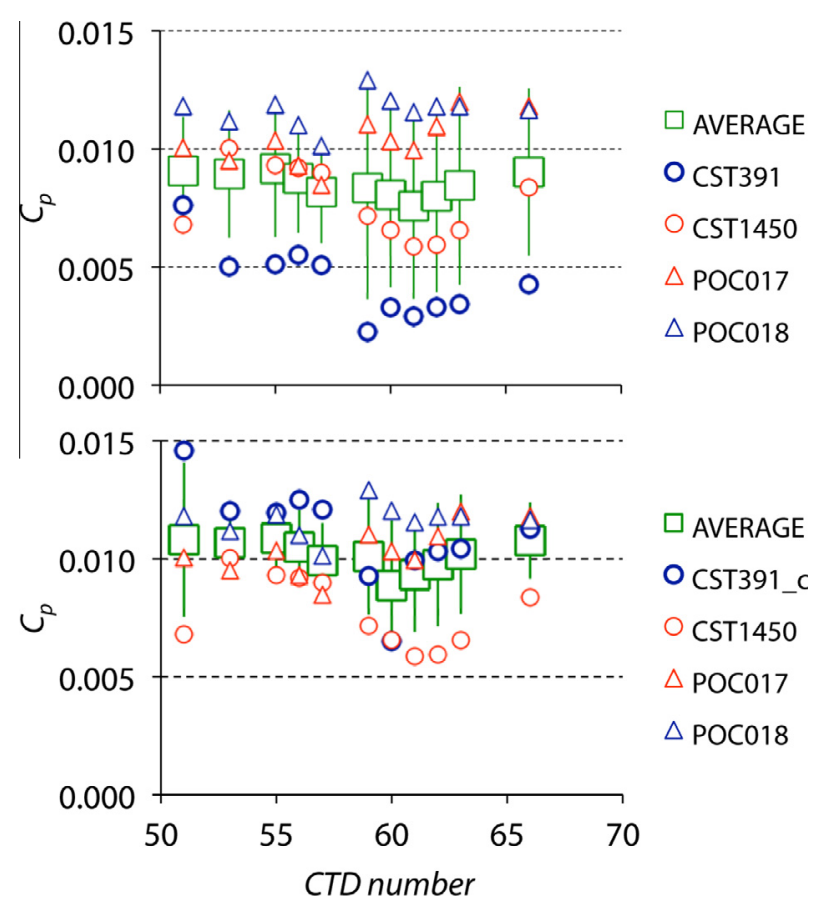

Fig. A1. Result of a test of 4 transmissometers R/V Point Sur, Feb 2012. Data represent the averages of beam attenuation coefficient over 3 days in a low variability layer from 1400-1600 m near Monterey Bay, CA. UPPER vs. LOWER panels are data from CST391 with and without a correction applied to account for thermal effects on transmissometer beam intensity. This correction adjustment resulted in an improved agreement between transmissometers from $\pm 0.0033 \mathrm{~m}^{-1}$ to $\pm 0.0021 \mathrm{~m}^{-1}$.

beam attenuation coefficient value to a precision of $\mathrm{s} . \mathrm{d}=0.0009 \mathrm{~m}^{-1}$. The largest contributor to the absolute disagreement of the 4 sensors was that each had a different and finite residual signal response to temperature, which although falling within manufacturer's specifications, is repeatable and can be compensated for during data processing. We were able to correct data from the older - less accurate analog sensor CST391 for temperature effects and brought all results into agreement of $\pm 0.0022 \mathrm{~m}^{-1}$. Manufacturer calibration of the sensor in particle free water has been shown to be reproducible. The residual thermal sensitivity issues of transmissometers can be solved.

\section{References}

Aas, E., 1996. Refractive index of phytoplankton derived from its metabolite composition. Journal of Plankton Research 18, 2223-2249.

Agrawal, Y.C., Pottsmith, H.C., 2000. Instruments for particle size and settling velocity observations in sediment transport. Marine Geology 168, 89-114.

Agrawal, Y.C., Whitmire, A., Mikkelsen, O.A., Pottsmith, H.C., 2008. Light scattering by random shaped particles and consequences on measuring suspended sediments by laser diffraction. Journal of Geophysical Research 113, C04023. http://dx.doi.org/10.1029/2007JC004403.

Alexander, S., Anderson, S., Hendry, D.C., Hobson, P.R., Lampitt, R.S., Lucas-Leclin, B. Nareid, H., Nebrensky, J.J., Player, M.A., Saw, K., Tipping, K., Watson, J., 2000. HoloCam: a subsea holographic camera for recording marine organisms and particles. Optical Diagnostics for Industrial Applications 4076, 111-119.

Alldredge, A., 1998. The carbon, nitrogen and mass content of marine snow as a function of aggregate size. Deep-Sea Research Part I-Oceanographic Research Papers 45, 529-541.

Alldredge, A.L., Jackson, G.A., 1995. Aggregation in marine systems. Deep-Sea Research Part-II 42, 1-7.

Alldredge, A.L., Passow, U., Logan, B.E., 1993. The abundance and significance of a class of large, transparent organic particles in the ocean. Deep-Sea Research, Part-I 40, 1131-1140.

Alvain, S., Moulin, C., Dandonneau, Y., Breon, F.M., 2005. Remote sensing of phytoplankton groups in case 1 waters from global SeaWiFS imagery. Deep-Sea Research Part I-Oceanographic Research Papers 52, 1989-2004.
Anderson, R.F., Hayes, C.T., 2015. Characterizing marine particles and their impact on biogeochemical cycles in the GEOTRACES program. Progress In Oceanography $133,1-5$

Asper, V.L., 1987. Measuring the flux and sinking speed of marine snow aggregates. Deep-Sea Research Part a-Oceanographic Research Papers 34, 1-17.

Asper, V.L., Honjo, S., Orsi, T.H., 1992. Distribution and transport of marine snow aggregates in the Panama Basin. Deep-Sea Research 39 (6A), 939-952.

Babin, M., Morel, A., Fournier-Sicre, V., Fell, F., Stramski, D., 2003. Light scattering properties of marine particles in coastal and open ocean waters as related to the particle mass concentration. Limnology and Oceanography $48,843-859$.

Baker, E.T., Tennant, D.A., Feely, R.A., Lebon, G.T., Walker, G.T., 2001. Field and laboratory studies on the effect of particle size and composition on optical backscattering measurements in hydrothermal plumes. Deep-Sea Research, Part-I 48, 593-604.

Balch, W.M., Utgoff, P.E., 2009. Potential interactions among ocean acidification, coccolithophores, and the optical properties of seawater. Oceanography 22, 146-159.

Balch, W.M., Drapeau, D.T., Fritz, J.J., Bowler, B.C., Nolan, J., 2001. Optical backscattering in the Arabian Sea - continuous underway measurements of particulate inorganic and organic carbon. Deep-Sea Research Part IOceanographic Research Papers 48, 2423-2452.

Balch, W., Drapeau, D., Bowler, B., Booth, E., 2007. Prediction of pelagic calcification rates using satellite measurements. Deep-Sea Research Part Ii-Topical Studies in Oceanography 54, 478-495.

Barnard, A.H., Pegau, W.S., Zaneveld, J.R.V., 1998. Global relationships of the inherent optical properties of the oceans. Journal of Geophysical ResearchOceans 103, 24955-24968.

Behrenfeld, M.J., Boss, E., 2006. Beam attenuation and chlorophyll concentration as alternative optical indices of phytoplankton biomass. Journal of Marine Research 64, 431-451.

Benfield, M.C., Grosjean, P., Culverhouse, P.F., Irigoien, X., Sieracki, M.E., LopezUrrutia, A., Dam, H.G., Hu, Q., Davis, C.S., Hansen, A., Pilskaln, C.H., Riseman, E.M., Schultz, H., Utgoff, P.E., Gorsky, G., 2007. RAPID research on automated plankton identification. Oceanography 20, 172-187.

Bishop, J.K.B., 1986. The correction and suspended particulate matter calibration of sea tech transmissometer data. Deep-Sea Research Part a-Oceanographic Research Papers 33, 121-134.

Bishop, J.K.B., 1999. Transmissometer measurement of POC. Deep-Sea Research Part I-Oceanographic Research Papers 46, 353-369.

Bishop, J.K.B., 2009. Autonomous observations of the ocean biological carbon pump. Oceanography 22, 182-193.

Bishop, J.K.B., Edmond, J.M., 1976. New large volume filtration system for sampling of oceanic particulate matter. Journal of Marine Research 34, 181-198.

Bishop, J.K.B., Joyce, T.M., 1986. Spatial distributions and variability of suspended particulate matter in warm-core ring 82b. Deep-Sea Research Part aOceanographic Research Papers 33, 1741-1760.

Bishop, J.K.B., Wood, T.J., 2008. Particulate matter chemistry and dynamics in the twilight zone at VERTIGO ALOHA and K2 sites. Deep Sea Research Part I: Oceanographic Research Papers 55, 1684-1706.

Bishop, J.K.B., Wood, T.J., 2009. Year round observations of carbon biomass and flux variability in the southern ocean. Global Biogeochemical Cycles 23, GB2019. http://dx.doi.org/10.1029/2008GB003206.

Bishop, J.K.B., Smith, R.C., Baker, K.S., 1992. Springtime distributions and variability of biogenic particulate matter in Gulf-Stream warm-core ring 82b and surrounding Nw Atlantic Waters. Deep-Sea Research Part a-Oceanographic Research Papers 39, S295-S325.

Bishop, J.K.B., Calvert, S.E., Soon, M.Y.S., 1999. Spatial and temporal variability of POC in the northeast Subarctic Pacific. Deep-Sea Research Part Ii-Topical Studies in Oceanography 46, 2699-2733.

Bishop, J.K.B., Davis, R.E., Sherman, J.T., 2002. Robotic observations of dust storm enhancement of carbon biomass in the North Pacific. Science 298, 817-821.

Bishop, J.K.B., Wood, T.J., Davis, R.E., Sherman, J.T., 2004. Robotic observations of enhanced carbon biomass and export at 55 degrees S during SOFeX. Science 304, 417-420.

Bishop, J.K.B., Lam, P.J., Wood, T.J., 2012. Getting good particles: accurate sampling of particles by large volume in-situ filtration. Limnology and Oceanography Methods 10, 681-710.

Boss, E., Pegau, W.S., Gardner, W.D., Zaneveld, J.R.V., Barnard, A.H., Twardowski, M.S., Chang, G.C., Dickey, T.D., 2001a. Spectral particulate attenuation and particle size distribution in the bottom boundary layer of a continental shelf. Journal of Geophysical Research-Oceans 106, 9509-9516.

Boss, E., Twardowski, M.S., Herring, S., 2001b. Shape of the particulate beam attenuation spectrum and its inversion to obtain the shape of the particulate size distribution. Applied Optics 40, 4885-4893.

Boss, E.S., Collier, R., Larson, G., Fennel, K., Pegau, W.S., 2007. Measurements of spectral optical properties and their relation to biogeochemical variables and processes in Crater Lake, Crater Lake National Park, OR. Hydrobiologia 574, 149-159.

Boss, E., Swift, D., Taylor, L., Brickley, P., Zaneveld, R., Riser, S., Perry, M.J., Strutton, P.G., 2008. Observations of pigment and particle distributions in the western North Atlantic from an autonomous float and ocean color satellite. Limnology and Oceanography 53, 2112-2122.

Boss, E., Slade, W., Hill, P., 2009a. Effect of particulate aggregation in aquatic environments on the beam attenuation and its utility as a proxy for particulate mass. Optics Express 17, 9408-9420. 
Boss, E., Slade, W.H., Behrenfeld, M., Dall'Olmo, G., 2009b. Acceptance angle effects on the beam attenuation in the ocean. Optics Express 17, 1535-1550.

Boss, E., Taylor, L., Gilbert, S., Gundersen, K., Hawley, N., Janzen, C., Johengen, T., Purcell, H., Robertson, C., Schar, D.W.H., Smith, G.J., Tamburri, M.N., 2009c. Comparison of inherent optical properties as a surrogate for particulate matter concentration in coastal waters. Limnology and Oceanography-Methods 7, 803810.

Boss, E., Picheral, M., Leeuw, T., Chase, A., Karsenti, E., Gorsky, G., Taylor, L., Slade, W., Ras, J., Claustre, H., 2013. The characteristics of particulate absorption, scattering and attenuation coefficients in the surface ocean. Contribution of the Tara Oceans expedition, Methods in Oceanography 7, 52-62.

Braithwaite, K.M., Bowers, D.G., Smith, W.A.M.N., Graham, G.W., 2012. Controls on floc growth in an energetic tidal channel. Journal of Geophysical ResearchOceans 117. http://dx.doi.org/10.1029/2011JC007094.

Brewer, P.G., Spencer, D.W., Biscaye, P.E., Hanley, A., Sachs, P.L., Smith, C.L., Kadar, S., Fredericks, J., 1976. The distribution of particulate matter in the Atlantic Ocean. Earth and Planetary Science Letters 32, 393-402.

Brewin, R.J.W., Hardman-Mountford, N.J., Lavender, S.J., Raitsos, D.E., Hirata, T., Uitz, J., Devred, E., Bricaud, A., Ciotti, A., Gentili, B., 2011. An intercomparison of biooptical techniques for detecting phytoplankton size class from satellite remote sensing. Remote Sensing of Environment 115, 325-339. http://dx.doi.org/ $10.1016 /$ j.rse.2010.09.004.

Briggs, N.T., Slade, W.H., Boss, E., Perry, M.J., 2013. Method for estimating mean particle size from high-frequency fluctuations in beam attenuation or scattering measurements. Applied Optics 52, 6710-6725.

Burd, A.B., Jackson, G.A., 2009. Particle aggregation. Annual Review in Marine Sciences 1, 65-90.

Burd, A.B., Jackson, G.A., Moran, S.B., 2007. The role of the particle size spectrum in estimating POC fluxes from disequilibrium. Deep Sea Research Part I: Oceanographic Research Papers 54, 897-918.

Cetinic, I., Perry, M.J., Briggs, N.T., Kallin, E., D’Asaro, E.A., Lee, C.M., 2012. Particulate organic carbon and inherent optical properties during 2008 North Atlantic Bloom Experiment. Journal of Geophysical Research-Oceans 117, C06028. http://dx.doi.org/10.1029/2011JC007771.

Chase, A., Boss, E., Zaneveld, R., Bricaud, A., Claustre, H., Ras, J., Dall'Olmo, G., Westberry, T., 2013. Decomposition of in situ particulate absorption spectra. Methods in Oceanography 7, 110-124. http://dx.doi.org/10.1016/ j.mio.2014.02.002.

Checkley, D.M., Davis, R.E., Herman, A.W., Jackson, G.A., Beanlands, B., Regier, L.A., 2008. Assessing plankton and other particles in situ with the SOLOPC. Limnology and Oceanography 53, 2123-2136.

Cowen, R.K., Guigand, C.M., 2008. In situ ichthyoplankton imaging system (ISIIS): system design and preliminary results. Limnology and Oceanography-Methods 6, 126-132.

Davis, R.F., Moore, C.C., Zaneveld, J.R.V., Napp, J.M., 1997. Reducing the effects of fouling on chlorophyll estimates derived from long-term deployments of optical instruments. Journal of Geophysical Research 102, 5851-5855.

Davis, C.S., Thwaites, F.T., Gallager, S.M., Hu, Q., 2005. A three-axis fast-tow digital Video Plankton Recorder for rapid surveys of plankton taxa and hydrography. Limnology and Oceanography-Methods 3, 59-74.

Deng, F., Thomas, A.L., Rijkenberg, M.J.A., Henderson, G.M., 2014. Controls on seawater ${ }^{231} \mathrm{~Pa},{ }^{230} \mathrm{Th}$ and ${ }^{232} \mathrm{Th}$ concentrations along the flow paths of deep waters in the Southwest Atlantic. Earth and Planetary Science Letters 390, 93102.

Dickey, T., Lewis, M., Chang, G., 2006. Optical oceanography: recent advances and future directions using global remote sensing and in situ observations. Reviews of Geophysics 44, RG 1001. http://dx.doi.org/10.1029/2003RG000148.

Dickey, T.D., Itsweire, E.C., Moline, M., Perry, M.J., 2008. Introduction to the Limnology and Oceanography Special Issue on Autonomous and Lagrangian Platforms and Sensors (ALPS). Limnology and Oceanography 53, 2057-2061.

Diercks, A.R., Asper, V.L., 1997. In situ settling speeds of marine snow aggregates below the mixed layer: Black Sea and Gulf of Mexico. Deep-Sea Research II 44, 385-397.

Dubelaar, G.B.J., Gerritzen, P.L., 2000. CytoBuoy: a step forward towards using flow cytometry in operational oceanography. Sciancias Marinas 64, 255-265.

Duysens, L.M.N., 1956. The flattening of the absorption spectrum of suspensions, as compared to that of solutions. Biochimica et Biophysica Acta 19, 1-12.

Estapa, M.L., Boss, E., Mayer, L.M., Roesler, C.S., 2012. Role of iron and organic carbon in mass-specific light absorption by particulate matter from Louisiana coastal waters. Limnology and Oceanography 57, 97-112.

Fournier, G. R., Sanjuan-Calzado, V., Trees, C., 2014. Implications of a new phase function for autonomous underwater imaging. In: Proc. SPIE 9111, Ocean Sensing and Monitoring VI, 911119, http://dx.doi.org/10.1117/12.2053878.

Fry, E.S., Kattawar, G.W., Pope, R.M., 1992. Integrating cavity absorption meter. Applied Optics 31, 2055-2065.

Gardner, W.D., 1977. Incomplete extraction of rapidly settling particles from water samplers. Limnology and Oceanography 22, 764-768.

Gardner, W.D., 1989a. Baltimore canyon as a modern conduit of sediment to the deep-sea. Deep-Sea Research Part a-Oceanographic Research Papers 36, 323358.

Gardner, W.D., 1989b. Periodic resuspension in Baltimore Canyon by focusing of internal waves. Journal of Geophysical Research 94, 18185-18194.

Gardner, W.D., Walsh, I.D., 1990. Distribution of macroaggregates and fine-grained particles across a continental-margin and their potential role in fluxes. DeepSea Research Part a-Oceanographic Research Papers 37, 401-411.
Gardner, W.D., Biscaye, P.E., Zaneveld, J.R.V., Richardson, M.J., 1985. Calibration and comparison of the LDGO nephelometer and the OSU transmissometer on the Nova Scotian rise. Marine Geology 66, 323-344.

Gardner, W.D., Walsh, I.D., Richardson, M.J., 1993. Biophysical forcing of particle production and distribution during a spring bloom in the North Atlantic. Deep Sea Research Part II: Topical Studies in Oceanography 40, 171-195.

Gardner, W.D., Richardson, M.J., Smith, W.O., 2000. Seasonal patterns of water column particulate organic carbon and fluxes in the Ross Sea, Antarctica. DeepSea Research II 47, 3423-3449.

Gardner, W.D., Blakey, J.C., Walsh, I.D., Richardson, M.J., Pegau, S., Zaneveld, J.R.V., Roesler, C., Gregg, M.C., MacKinnon, J.A., Sosik, H.M., Williams III, A.J., 2001. Optics, particles, stratification and storms on the New England continental shelf. Journal of Geophysical Research 106, 9473-9497.

Gardner, W.D., Richardson, M.J., Carlson, C.A., Hansell, D., Mishonov, A.V., 2003 Determining true particulate organic carbon: bottles, pumps and methodologies. Deep-Sea Research Part Ii-Topical Studies in Oceanography 50, 655-674.

Gardner, W.D., Richardson, M.J., Mishonov, A.V., Biscaye, P.E., 2014. Global Distribution And Intensity Of Deep-Water Benthic Nepheloid Layers - What Satellites, Floats And Gliders Don't See. Ocean Sciences Meeting, Hawaii.

Goldthwait, S.A., Alldredge, A.L., 2006. An investigation of diel synchronicity between water column marine snow concentration and the flux of organic matter in the Santa Barbara Channel, California. Deep-Sea Research Part IOceanographic Research Papers 53, 485-505.

Gonzalez-Quiros, R., Checkley, D.M., 2006. Occurrence of fragile particles inferred from optical plankton counters used in situ and to analyze net samples collected simultaneously. Journal of Geophysical Research - Oceans 111, 5-6.

Gorsky, G., Aldorf, C., Kage, M., Picheral, M., Garcia, Y., Favole, J., 1992. Verticaldistribution of suspended aggregates determined by a new underwater video profiler. Annales De L Institut Oceanographique 68, 275-280.

Guay, C.K.H., Bishop, J.K.B., 2002. A rapid birefringence method for measuring suspended $\mathrm{CaCO}_{3}$ concentrations in seawater. Deep-Sea Research Part IOceanographic Research Papers 49, 197-210.

Guidi, L., Jackson, G.A., Stemmann, L., Miquel, J.C., Picheral, M., Gorsky, G., 2008 Relationship between particle size distribution and flux in the mesopelagic zone. Deep-Sea Research Part I-Oceanographic Research Papers 55, 1364-1374.

Guidi, L., Stemmann, L., Jackson, G.A., Ibanez, F., Claustre, H., Legendre, L., Picheral, M., Gorsky, G., 2009. Effects of phytoplankton community on production, size and export of large aggregates: a world-ocean analysis. Limnology and Oceanography 54, 1951-1963.

Guidi, L., Calil, P.H.R., Duhamel, S., Björkman, K.M., Doney, S.C., Jackson, G.A., Li, B., Church, M.J., Tozzi, S., Kolber, Z.S., Richards, K.J., Fong, A.A., Letelier, R.M. Gorsky, G., Stemmann, L., Karl, D.M., 2012. Does eddy-eddy interaction control surface phytoplankton distribution and carbon export in the North Pacific Subtropical Gyre? Journal of Geophysical Research 117, G02024.

Hayes, C.T., Anderson, R.F., Fleisher, M.Q., Huang, K.F., Robinson, L.F., Lu, Y., Cheng, H., Edwards, R.L., Moran, S.B., in press. ${ }^{230} \mathrm{Th}$ and ${ }^{231} \mathrm{~Pa}$ on GEOTRACES GA03, the U.S. GEOTRACES North Atlantic transect and implications for modern and paleoceanographic chemical fluxes. Deep Sea Research Part II: Topical Studies in Oceanography, http://dx.doi.org/10.1016/j.dsr2.2014.07.007i.

Hill, P.S., Boss, E., Newgard, J.P., Law, B.A., Milligan, T.G., 2011. Observations of the sensitivity of beam attenuation to particle size in a coastal bottom boundary layer. Journal of Geophysical Research-Oceans 116, C02023. http://dx.doi.org/ 10.1029/2010JC006539.

Hobson, P.R., Krantz, E.P., Lampitt, R.S., Rogerson, A., Watson, J., 1997. A preliminary study of the distribution of plankton using hologrammetry. Optics and Laser Technology 29, 25-33.

Holser, R.R., Goni, M.A., Hales, B., 2011. Design and application of a semi-automated filtration system to study the distribution of particulate organic carbon in the water column of a coastal upwelling system. Marine Chemistry 123 (1-4), 6777. http://dx.doi.org/10.1016/j.marchem.2010.10.001.

Honjo, S., Doherty, K.W., Agrawal, Y.C., Asper, V.L., 1984. Direct optical assessment of large amorphous aggregates (Marine Snow) in the deep ocean. Deep-Sea Research Part a-Oceanographic Research Papers 31, 67-76.

IOCCG, 2006. Remote sensing of inherent optical properties: fundamentals, tests of algorithms, and applications. In: Lee, Z.P. (Ed.), Reports of the International Ocean-Colour Coordinating Group, No. 5, IOCCG, Dartmouth, Canada.

IOCCG, 2011. Bio-Optical Sensors on Argo Floats. Claustre, H. (ed.), Reports of the International Ocean-Colour Coordinating Group, No. 11, IOCCG, Dartmouth, Canada.

IOCCG, 2014. Phytoplankton Functional Types from Space. In: Sathyendranath, S. (Ed.), Reports of the International Ocean-Colour Coordinating Group, No. 15, IOCCG, Dartmouth, Canada.

Iversen, M.H., Nowald, N., Ploug, H., Jackson, G.A., Fischer, G., 2010. High resolution profiles of vertical particulate organic matter export off Cape Blanc, Mauritania: degradation processes and ballasting effects. Deep-Sea Research Part IOceanographic Research Papers 57, 771-784.

Jackson, G., Burd, A., 2002. A model for the distribution of particle flux in the midwater column controlled by subsurface biotic interactions. Deep-Sea Research Il 49, 193-217.

Jackson, G.A., Checkley, D.M., 2011. Particle size distributions in the upper $100 \mathrm{~m}$ water column and their implications for animal feeding in the plankton. DeepSea Research Part I: Oceanographic Research Papers 58, 283-297.

Jackson, G.A., Maffione, R., Costello, D.K., Alldredge, A.L., Logan, B.E., Dam, H.G. 1997. Particle size spectra between $1 \mu \mathrm{m}$ and $1 \mathrm{~cm}$ at Monterey Bay determined 
using multiple instruments. Deep Sea Research Part I: Oceanographic Research Papers 44, 1739-1767.

Jeandel, C., Rutgers van der Loeff, M., Kretschmer, S., Lam, P.J., Sherrell, R.M., RoyBarman, M., German, C.R., Dehairs, F., 2015. What did we learn on the oceanic particle dynamic from the GEOSECS-JGOFS times? Progress in Oceanography 133, 6-16.

Jonasz, M., Fournier, G., 2007. Light Scattering by Particles in Water: Theoretical and Experimental Foundations. Elsevier, Amsterdam.

Jouandet, M.P., Trull, T.W., Guidi, L., Picheral, M., Ebersbach, F., Stemmann, L., Blain, S., 2011. Optical imaging of mesopelagic particles indicates deep carbon flux beneath a natural iron-fertilized bloom in the Southern Ocean. Limnology and Oceanography 56, 1130-1140.

Karageorgis, A., Gardner, W.D., Georgopoulos, D., Mishonov, A.V., Krasakopoulou, E., Anagnostou, C., 2008. Particle dynamics in the Eastern Mediterranean Sea: a synthesis based on light transmission, PMC, and POC archives (1991-2001). Deep-Sea Research I 55, 177-202. http://dx.doi.org/10.1016/j.dsr.2007.11.002.

Karageorgis, A.P., Gardner, W.D., Mikkelsen, O.A., Georgopoulos, D., Ogston, A.S., Assimakopoulou, G., Krasakopoulou, E., Oaie, Gh., Secrieru, D., Kanellopoulos, Th.D., Pagou, K., Anagnostou, Ch., Papathanassiou, E., 2014. Particle sources over the Danube River Delta, Black Sea based on distribution, composition and size using optics, imaging and bulk analyses. Journal of Marine Systems 131, 74-90.

Karp-Boss, L., Wheeler, P.A., Hales, B., Covert, P., 2004. Distributions and variability of particulate organic matter in a coastal upwelling system. Journal of Geophysical Research 109, C09010. http://dx.doi.org/10.1029/2003JC002184.

Karp-Boss, L., Azevedo, L., Boss, E., 2007. LISST-100 measurements of phytoplankton size distribution: evaluation of the effects of cell shape. Limnology and Oceanography-Methods 5, 396-406.

Katz, J., Donaghay, P., Zhang, J., King, S., Russell, K., 1999. Submersible holocamera for detection of particle characteristics and motions in the ocean. Deep-Sea Research Part I 46, 1455-1481.

Kostadinov, T.S., Siegel, D.A., Maritorena, S., 2009. Retrieval of the particle size distribution from satellite ocean color observations. Journal of Geophysical Research-Oceans 114, C09015. http://dx.doi.org/10.1029/2009JC005303.

Kostadinov, T.S., Siegel, D.A., Maritorena, S., 2010. Global variability of phytoplankton functional types from space: assessment via the particle size distribution. Biogeosciences 7, 3239-3257.

Lam, P.J., Twining, B.S., Jeandel, C., Roychoudhury, A.N., Resing, J., Geibert, W., Santschi, P., Anderson, R.F., 2015. Methods for analyzing the concentration and speciation of major and trace elements in marine particles. Progress in Oceanography $133,32-42$

Lerner, P., Bishop, J.K.B., Strubhar W.D., Bernard, A., Moore, C., 2013. Transmissometer measurement of particle beam attenuation coefficient. ALSO Ocean Sciences Meeting Session SS53-380. New Orleans Feb 16-21 2013.

Leymarie, E., Doxaran, D., Babin, M., 2010. Uncertainties associated to measurements of inherent optical properties in natural waters. Applied Optics 49, 5415-5436.

Loisel, H., Nicolas, J.-M., Sciandra, A., Stramski, D., Poteau, A., 2006. Spectral dependency of optical backscattering by marine particles from satellite remote sensing of the global ocean. Journal of Geophysical Research 111, C09024. http://dx.doi.org/10.1029/2005JC003367.

Loisel, H., Meriaux, X., Berthon, J.F., Poteau, A., 2007. Investigation of the optical backscattering to scattering ratio of marine particles in relation to their biogeochemical composition in the eastern English Channel and southern North Sea. Limnology and Oceanography 52, 739-752.

MacIntyre, H. L., Lawrenz, E., Richardson, T.L., 2010. Taxonomic Discrimination of Phytoplankton by Spectral Fluorescence. Ch. 7 In: D.J. Chlorophyll a Fluorescence in Aquatic Sciences: Methods and Applications, Developments in Applied Phycology 4, Suggett et al. (Eds.), Springer http://dx.doi.org/10.1007/ 978-90-481-9268-7_7.

McDonnell, A.M.P., Buesseler, K.O., 2010. Variability in the average sinking velocities of marine particles. Limnology and Oceanography 55, 2085-2096.

McDonnell, A.M.P., Lamborg, C.H., Buesseler, K.O., Lam, P.J., Sanders, R., Smith, H. Sargent, E.C., Riley, J.S., Lampitt, R.S., Marsay, C. and Bishop, J.K.B., 2015. A summary of techniques for the collection of marine particles. Progress in Oceanography $133,17-31$

McKee, D., Chami, M., Brown, I., Sanjuan Calzado, V., Doxaran, D., Cunningham, A. 2009. Role of measurement uncertainties in observed variability in the spectra backscattering ratio: a case study in mineral-rich coastal waters. Applied Optics 48, 4663-4675.

Moisan, J.R., Moisan, T.A.H., Linkswiler, M.A., 2011. An inverse modeling approach to estimating phytoplankton pigment concentrations from phytoplankton absorption spectra. Journal of Geophysical Research-Oceans 116, C09018. http://dx.doi.org/10.1029/2010JC006786.

Moran, S.B., Charette, M.A., Pike, S.M., Wicklund, C.A., 1999. Differences in seawate particulate organic carbon concentration in samples collected using small- and large volume methods: the importance of DOC adsorption to the filter blank. Marine Chemistry 67, 33-42.

Neukermans, G., Loisel, H., Meriaux, X. Astoreca, R. Mckee, D., 2012. In situ variability of mass-specific beam attenuation and backscattering of marine particles with respect to particle size, density, and composition. Limnology and Oceanography 57, 124-144.

Olson, R.J., Sosik, H.M., 2007. A submersible imaging-in-flow instrument to analyze nano-and microplankton: imaging FlowCytobot. Limnology and OceanographyMethods 5, 195-203.
O’Reilly, J.E., Maritorena, S., Mitchell, B.G., Siegel, D.A., Carder, K.L., Garver, S.A., Kahru, M. McClain, C., 1998. Ocean color chlorophyll algorithms for SeaWiFS. Journal of Geophysical Research-Oceans 103, 24937-24953.

Peterson, M.L., Wakeham, S.G., Askea, M.A., Miquel, J.C., 2005. Novel techniques for collection of sinking particles in the ocean and determining their settling rates. Limnology and Oceanography: Methods 3, 520-532.

Pfitsch, D.W., Malkiel, E., Takagi, M., Ronzhes, Y., King, S., Sheng, J., Katz, J., 2007. Analysis of in-situ microscopic organism behavior in data acquired using a freedrifting submersible holographic imaging system. Oceans 1-5, 583-590.

Picheral, M., Guidi, L., Stemmann, L., Karl, D.M., Iddaoud, G., Gorsky, G., 2010. The Underwater Vision Profiler 5: an advanced instrument for high spatial resolution studies of particle size spectra and zooplankton. Limnology and Oceanography-Methods 8, 462-473.

Reynolds, R.A., Stramski, D., Wright, V.M., Wozniak, S.B., 2010. Measurements and characterization of particle size distributions in coastal waters. Journal of Geophysical Research-Oceans 115. http://dx.doi.org/10.1029/2009JC005930.

Richardson, M. J., Gardner, W.D., Berglund, B.L., and Walsh, I.D., 1990. Global distribution of biogenic and particulate matter: What satellites can't see, but transmissometers can. EOS, Trans. Amer. Geophys. Union, 71, 136.

Richardson, M.J., Weatherly, G.L., Gardner, W.D., 1993. Benthic storms in the Argentine Basin. Deep-Sea Research Part Ii-Topical Studies in Oceanography 40, 975-987.

Röttgers, R., McKee, D., Woźniak, S.B., 2013. Evaluation of scatter corrections for ac9 absorption measurements in coastal waters. Methods in Oceangraphy 7, 2139.

Roullier, F., Berline, L., Guidi, L., Sciandra, A., Durrieu de Madron, X., Picheral, M. Pesant, S., Stemmann, L., 2014. Particles size distribution and carbon flux across the Arabian Sea Ocean Oxygen Minimum Zone. Biogeosciences 11, 4541-4557.

Samson, S., Hopkins, T., Remsen, A., Langebrake, L., Sutton, T., Patten, J., 2001. A system for high-resolution zooplankton imaging. Ieee Journal of Oceanic Engineering 26, 671-676.

Shifrin, K.S., 1988. The method of fluctuations. In: Physical Optics of Ocean Water. American Institute of Physics, 1988, pp. 224-232.

Sieracki, C.K., Sieracki, M.E., Yentsch, C.S., 1998. An imaging-in-flow system for automated analysis of marine microplankton. Marine Ecolology Progress Series $168,285-296$.

Slade, W.H., Boss, E., Dall'Olmo, G., Langner, M.R., Loftin, J., Behrenfeld, M.J., Roesler, C., Westberry, T.K., 2010. Underway and moored methods for improving accuracy in measurement of spectral particulate absorption and attenuation. Journal of Atmospheric and Oceanic Technology 27 (10), 1733-1746.

Slade, W.H., Boss, E., Russo, C., 2011. Effects of particle aggregation and disaggregation on their inherent optical properties. Optics Express 19, 79457959.

Son, Y.B., Gardner, W.D., Mishonov, A.V., Richardson, M.J., 2009. Multispectral remote-sensing algorithms for particulate organic carbon (POC): the Gulf of Mexico. Remote Sensing of Environment 113, 50-61.

Sosik, H.M., 2008. Characterizing seawater constituents from optical properties. In: Babin, M., Roesler, C.S., Cullen, J.J. (Eds.), Real-time Coastal Observing Systems for Ecosystem Dynamics and Harmful Algal Blooms: Theory, instrumentation and modelling. UNESCO, p. 281-329.

Stemmann, L., Boss, E, 2012. Plankton and particle size and packaging: from determining optical properties to driving the biological pump. Annual Review of Marine Science 4 (4), 263-290.

Stemmann, L., Jackson, G.A., Gorsky, G., 2004a. A vertical model of particle size distributions and fluxes in the midwater column that includes biological and physical processes - Part II: application to a three year survey in the NW Mediterranean Sea. Deep-Sea Research Part I-Oceanographic Research Papers 51, 885-908.

Stemmann, L., Jackson, G.A., Ianson, D., 2004b. A vertical model of particle size distributions and fluxes in the midwater column that includes biological and physical processes - Part I: model formulation. Deep-Sea Research Part IOceanographic Research Papers 51, 865-884.

Stemmann, L., Youngbluth, M., Robert, K., Hosia, A., Picheral, M., Paterson, H., Ibanez, F., Guidi, L., Lombard, F., Gorsky, G., 2008a. Global zoogeography of fragile macrozooplankton in the upper $100-1000 \mathrm{~m}$ inferred from the underwater video profiler. Ices Journal of Marine Science 65, 433-442.

Stemmann, L., Eloire, D., Sciandra, A., Jackson, G.A., Guidi, L., Picheral, M., Gorsky, G., 2008b. Volume distribution for particles between 3.5 to $2000 \mu \mathrm{m}$ in the upper $200 \mathrm{~m}$ region of the South Pacific Gyre. Biogeosciences 5, 299-310.

Stramski, D., Reynolds, R.A., Kahru, M., Mitchell, B.G., 1999. Estimation of particulate organic carbon in the ocean from satellite remote sensing. Science 285, 239242.

Stramski, D., Reynolds, R.A., Babin, M., Kaczmarek, S., Lewis, M.R., Rottgers, R., Sciandra, A., Stramska, M., Twardowski, M.S., Franz, B.A., Claustre, H., 2008. Relationships between the surface concentration of particulate organic carbon and optical properties in the eastern South Pacific and eastern Atlantic Oceans. Biogeosciences 5, 171-201.

Sullivan, J., Twardowski, M., Zaneveld, J.R.V., Moore, C., 2013. Measuring optical backscattering in water. In: Kokhanovsky, A. (Ed.), Light Scattering Reviews 7: Radiative Transfer and Optical Properties of Atmosphere and Underlying Surface, Springer Praxis Books, pp. 189-224 http://dx.doi.org/10.1007/978-3642-21907-8 6

Twardowski, M.S., Boss, E., Macdonald, J.B., Pegau, W.S., Barnard, A.H., Zaneveld, J.R.V., 2001. A model for estimating bulk refractive index from the optical backscattering ratio and the implications for understanding particle 
composition in case I and case II waters. Journal of Geophysical ResearchOceans 106, 14129-14142.

Twardowski, M.S., Claustre, H., Freeman, S.A., Stramski, D., Huot, Y., 2007. Optical backscattering properties of the 'clearest' natural waters. Biogeosciences 4 , 1041-1058.

Vantrepotte, V., Loisel, H., Meriaux, X., Neukermans, G., Dessailly, D., Jamet, C., Gensac, E., Gardel, A., 2011. Seasonal and inter-annual (2002-2010) variability of the suspended particulate matter as retrieved from satellite ocean color sensor over the French Guiana coastal waters. Journal of Coastal Research, $1750-1754$.
Walsh, I.D., Gardner, W.D., 1992. A comparison of aggregate profiles with sediment trap fluxes. Deep-Sea Research Part a-Oceanographic Research Papers 39, 1817 1834.

Walsh, R.S., Hunter, K.A., 1992. Influence of phosphorus storage on the uptake of cadmium by the Marine Alga Macrocystis-Pyrifera. Limnology and Oceanography 37, 1361-1369.

Werdell, P.J. et al., 2013. Generalized ocean color inversion model for retrieving marine inherent optical properties. Applied Optics 52, 2019-2037.

Wood, M.M., Particulate Matter in the South Atlantic Ocean. 1993. MS Thesis, Texas A\&M University, $84 \mathrm{pp}$. 